\title{
Stage IIC Ovarian Cancer AJCC v6 and v7
}

National Cancer Institute

\section{Source}

National Cancer Institute. Stage IIC Ovarian Cancer A/CC v6 and v7. NCI Thesaurus. Code C5225.

Stage IIC includes: T2c, N0, M0. T2c: Pelvic extension and/or implants (T2a or T2b) with malignant cells in ascites or peritoneal washing. NO: No regional lymph node metastasis. M0: No distant metastasis. (AJCC 6th and 7th eds.) 